\title{
The Effect of Methyltestosterone Hormone Immersion on Male Formation in Gourami Larvae (Osphronemus goramy Lacepède, 1801)
}

\author{
Tatang $^{1^{*}}$, Maheno Sriwidodo ${ }^{2}$, Harsuko Riniwati ${ }^{2}$ \\ ${ }^{1}$ Master Program of Aquaculture, Faculty of Fisheries and Marine Sciences, University of Brawijaya, Malang, Indonesia \\ ${ }^{2}$ Faculty of Fisheries and Marine Sciences, University of Brawijaya, Malang, Indonesia
}

\begin{abstract}
The methyltestosterone hormone is a synthetic hormone of androgen and has been used to obtain the juveniles of male mono-sexual fish such as Tetra Congo, Tilapia, and Betta. The methyltestosterone use on gourami has not maximized. It because there is no data on the exact age of larvae to produce maximum male mono-sexual juveniles, so it is necessary to do research on the effect of methyltestosterone hormone on the age of gourami larvae on the success of male mono-sexual formation and get the right larval period to obtain maximum survival gourami. The methods of this research were conducted using a completely randomized design with four treatments of the age of gourami larvae aged ten days, 15 days, 20 days, and 25 days. Each procedure was repeated three times. Data analysis used ANOVA analysis and LSD test. The larvae are soaked in a solution containing $5 \mathrm{ppm}$ of hormones for 24 hours. The results showed that the administration of the hormone methyltestosterone to gourami larvae (Osphronemus goramy Lacepède, 1801) with different ages had a very significant effect $(P<0.01)$ on male sex formation with the highest average percentage of males obtained in treatment B (15-day larvae age) that is equal to $82.33 \%$ and the lowest in the treatment of larval period of 10 and 20 days is $74.00 \%$.
\end{abstract}

Keywords: Gourami, hormone, juvenile, methyltestosterone, Osphronemus goramy.

\section{INTRODUCTION}

The Giant Gourami (Osphronemus goramy) is an important commodity fish culture in Indonesia. They grow at a relatively slow rate, which can hinder efforts to increase production to meet high consumer demand. However, if increasing the production of this fish is difficult, it may be possible to increase the growth of each gourami fish. There are several known strategies to increasing the fish growth rate through the masculinization application.

Producing mono-sex juveniles means producing fish with one sex, only male or female. It is based on different fish growth patterns between male and female fish. In gourami, the growth of male fish is faster than female fish, males aged 10-12 months can reach an average weight of $250 \mathrm{~g}$ per head, whereas females only $200 \mathrm{~g}$ per head [1]. It means male growth is $20 \%$ faster than females. So by only producing male fish seeds can increase production from gourami enlargement efforts.

The primary approach to commercial applications of male populations is through hormonal and selective breeding that has produced a large interest. Sex reversal, manual sexing, hybridization, and super male production are different methods available to obtain the

\footnotetext{
${ }^{*}$ Correspondence address:

Tatang

Email : t4atank@gmail.com

Address : Faculty of Fisheries and Marine Sciences, University of Brawijaya, Veteran Malang, 65145.
}

desired sex population. The hormonal sex reversal has been used as a valuable key tool in sex manipulation for aquaculture. There are several reports on the use of steroid hormone for successful induction of functional sex in ornamental fish that exist [2-5]. Sex reversal by immersion treatment with methyltestosterone (MT) is the most effective and practical method for the production of the all-male population.

The methyltestosterone hormone is a synthetic androgen hormone. This hormone has been widely used to obtain male mono-sex fish juveniles [6] and Louhan fish [7]. For gourami fish, methyltestosterone hormone with a dose of 5 mg.t $\mathrm{L}^{-1}$ can produce $66.98 \%$ of male gourami seeds [7]. However, these results have not been maximized. Unlike in Tilapia whose, the success rate can reach $90-100 \%$ male mono-sex. It is because data about the exact age of gouramy juveniles have not been obtained to produce maximum male mono-sex juveniles. This study aimed to evaluate the administration of methyltestosterone effect on the masculinization of juveniles of Gourami (O. goramy).

\section{MATERIAL AND METHOD}

This research was carried out in the Fish Reproduction Laboratory of State University of Malang. The study used a completely randomized design with four treatments of gourami larvae age ( 10 days, 15 days, 20 days, and 25 days) each procedure was repeated three times. Data analysis used ANOVA analysis and LSD test. One 
hundred larvae per plastic bag were immersed in a solution containing five ppm of hormones for 24 hours for each treatment. The success of male-female formation was observed right after one month of morphological and histological maintenance [3], and survival of gourami fish was found at the end of the study.

\section{RESULTS AND DISCUSSION \\ Percentage of Male Gourami}

Giving methyltestosterone hormone at a dose of $5 \mathrm{ppm}$ in the larvae of gourami fish aged 10, 15,20 , and 25 days after hatching by soaking for 24 hours. From the observations obtained the average data on the percentage of successful sex formation of gourami fish (Osphronemus gourami Lac.) presented in Table 1.

Table 1. Success Data of Sex Formation (\%)

\begin{tabular}{ccc}
\hline Age of juvenile & Male (\%) & Female (\%) \\
\hline 10-day & 75.00 & 25.00 \\
15 day & 82.33 & 17.67 \\
20 day & 76.33 & 24.67 \\
25 day & 74.00 & 26.00 \\
\hline
\end{tabular}

From Table 1, the results of the highest percentage of successful male sex formation were found in the treatment of 15-day-old larvae $(82.33 \%)$. Meanwhile, the lowest portion of the successful male-sex structure was found in the treatment of 25-day-old fish larvae with the same value $(74.00 \%)$ - the survival rate of gourami fish during one month of maintenance ranging from $74 \%$ to $82.33 \%$.

The results of the variance above show that the administration of the methyltestosterone hormone gourami larvae (Osphronemus gourami) significantly affected the formation of male sex marked from the $F$ count $>F$ table $5 \%$. So it continues on the Least Significant Difference test.

Tests of four different treatments for gourami larvae, the highest average percentage of males, were obtained in the treatment of 15-day fish larvae at $82.33 \%$, and the lowest was at 25 -day larvae treatments at $74.00 \%$. It proves that with the age of 15 days, gourami fish larvae can direct changes in the direction of the higher male sex.

When the fish is 15 days old, the larvae have managed to direct the direction of their genitals into males by $82.33 \%$. This means it is more effective and efficient when compared with previous studies [4], namely, the administration of the hormone methyltestosterone $5 \mathrm{mg} \cdot \mathrm{L}^{-1}$ to 21-day-old fish seed yields males $66.98 \%$ and requires soaking time of 3-6 hours [5]. The success of male sex formation when the fish is 15 days old of larvae is due to the right dose of hormones and is given at the correct phase, i.e., when the body is still smooth so that hormones are absorbed effectively through the skin by diffusion without being blocked by scales. Table 1 also shows that as the age of Gourami larvae increases, the percentage of males tends to decrease. It is because the bigger/older fish indicates that the fish has undergone a process of differentiation, fish that have differentiated channels and genitals have been formed so that the hormone methyltestosterone given will be challenging to influence sex changes. Besides, other factors that play a role in the process of sex formation are fish species, stocking densities, and environmental conditions.

Administration of steroid hormones is carried out when the gonad is still not formed (differentiated) and continues to be given until sex is fully differentiated, this will produce all males but $50 \%$ of the fish genotype produced by females [6]. The criteria for effective stimulation of sex reversal, namely steroid hormones are given when the gonad is still not formed and the treatment is carried out continuously until differentiated and the dose used must be sufficient and appropriate [7].

The effect of hormones on fish species has been studied. Methyltestosterone administration to Tilapia zillii after four weeks of age does not affect sexual changes and development [7]. Soaking eggs with eyespot and larvae of coho salmon in a methyltestosterone solution with a concentration of $25 \mu \mathrm{g} . \mathrm{L}^{-1}$ was successful in changing the male sex to $100 \%$. According to these results, it can be concluded that the treatment of hormonal doses must be appropriate and at the right age of the fish, and the dosage is specific to each fish species [8].

\section{Survival Rate}

The survival rate of gourami during one month of maintenance obtained data ranging from $70.76 \%-80 \%$. Data on survival in different larval ages can be seen in Figure 1.

During the maintenance period, the resulting life tends to be at a low rate. The low survival rate in this study is due to unstable temperatures wherein the morning it is too cold, and in the afternoon, the temperature is too hot, so the changing water conditions trigger the emergence of mold and make the fish condition often experience stress and die. This unstable temperature change took place from the beginning of the study up to 55 days during the 
study. Therefore, the survival rate of gourami fish was low.

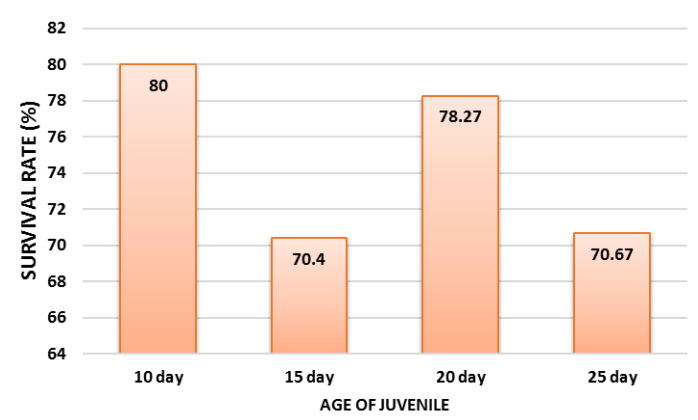

Figure 1. The survival rate of gourami during one month of maintenance.

\section{Water Quality}

For water quality during pond maintenance, the morning data was $22-25^{\circ} \mathrm{C}$, afternoon for 27 $30^{\circ} \mathrm{C}$ and evening at $24-25^{\circ} \mathrm{C}$. Where the ideal temperature for support of gourami is $24-28^{\circ} \mathrm{C}$ [9]. Ranges of $\mathrm{pH}$ were 6.5-7.4 while the degree of acidity $(\mathrm{pH})$ of water suitable for juvenile of gourami ranges from $6-8$, and the dissolved oxygen ranges from $4-5 \mathrm{mg} \cdot \mathrm{L}^{-1}$ while the best oxygen content for carp is between $4-6 \mathrm{mg} . \mathrm{L}^{-1}$ [9].

\section{REFERENCES}

[1] Pandian, T.J., K. Varadaraj. 1990. Techniques for produce $100 \%$ male Tilapia. Naga, The ICLARM Quarterly. 13(34). 3-5.

[2] Gale, W.L., Fitzpatrick M S, Lucero $M$, Contreras-Sanchez W Mand Schreck C B.1999. Masculinization of Nile tilapia (Oreochromis niloticus) by immersion in androgens. Aquaculture. 178. 349-57.

[3] George, T., T.J. Pandian. 1996. Hormonal induction of sex reversal and progeny testing in the zebra cichlid. Cichlasomanigro fasciatum. J. Exp. Zool. 275. 374-382.

[4] Pandey, G. 2013. Feed formulation and Feeding technology for fishes. Int. Res. J. Pharm. 4(3). 23-30.

[5] Zairin, M. Jr. 2000. Pengaruh pemberian bioenkapsulat $17 \alpha$-Metiltestosteron di dalam artemia terhadap nisbah kelamin ikan cupang (Betta splendens). Sains Akuantik. 3. 1-8.

[6] Handajani, H. 2006. Pengujian hormon metiltestosteron terhadap keberhasilan pembentukan monosex jantan ikan gurami (Osphronemus gouramy). Jurnal Protein 13(1). 60-69.

[7] Aliu, B., J. Afolabi, M. Egwenomhe, A. Esume. 2017. Survey on nutrition and feeding practices of fish by farmers in Ondo State, Nigeria. Asian J. Biol. 2(1). 1-9.
[8] Handajani, H. 2006. Perendaman larva gourami (Osphronemus gourami) dengan umur yang berbeda pada hormon methyltestosterone terhadap keberhasilan pembentukan mono-sexual jantan. Jurnal Protein. 15(2).

[9] Handajani, H. 2006. Pengujian hormon methyltestosteronee terhadap keberhasilan pembentukan mono-sexual jantan ikan gourami (Osphronemus gourami). Jurnal Protein. 13(1). 60-69.

[10] Arifin, T.M., H. Handajani. 2005. Optimalisasi dosis hormone methyltestosteronee dan lama perendaman benih ikan gourami (Osphronemus gourami Lac.) terhadap keberhasilan kelamin jantan. Research Report. FPP-UMM. Malang.

[11] Zairin, M. Jr., Waskitaningtyas, K. Nasrum. Sumantadinata, 2001. Pengaruh Pemberian Artemia yang Direndam di dalam Larutan 17 $\alpha$-Methyltestosteronee Berdosis Rendah terhadap Nisbah Kelamin Ikan Cupang (Betta splendens Regan). Aquaculture Indonesia. 2. 107-112.

[12] Guerrero, R.D., W.L. Shelton. 1974. An aceto-carmine squash method for sexing juvenile fishes. The Progressive FishCulturist. 36(1). 56-56.

[13] Yamazaki, F. 1983. Sex differentiation. In: Hoar, W.S., D.J. Randal (Eds). Fish Physiology, Vol. III. Academic Press. New York. 117-158.

[14] Sitanggang, M., B. Sarowono. 2007. Budi daya gourami: Edisi Revisi. Penebar Swadaya. Jakarta. 